\title{
Husserl's covert critique of Kant in the sixth book of Logical Investigations
}

\section{Corijn van Mazijk ${ }^{1}[$ ]}

Published online: 19 October 2018

(c) The Author(s) 2018

\begin{abstract}
In the final book of Logical Investigations from 1901, Husserl develops a theory of knowledge based on the intentional structure of consciousness. While there is some textual evidence that Husserl considered this to entail a critique of Kantian philosophy, he did not elaborate substantially on this. This paper reconstructs the covert critique of Kant's theory of knowledge which LI contains. With respect to Kant, I discuss three core aspects of his theory of knowledge which, as Husserl's reflections on Kant indicate, Husserl was familiar with. These are (i) the cooperation of two faculties for the justification of beliefs; (ii) the concept of a priori structures of knowledge Kant operated with; and (iii) the delivered transcendental proof of these structures. Regarding Logical Investigations, I first briefly outline the intentional structure of consciousness as presented in the fifth book and then turn to the theory of knowledge in the sixth book. I then clarify, partially on the basis of manuscripts and lecture notes, the covert critique of the three core aspects of Kant's theory which the sixth book contains.
\end{abstract}

Keywords Husserl · Kant · Logical Investigations · Theory of knowledge · Evidence $\cdot$ A priori $\cdot$ Transcendental

Corijn van Mazijk

c.m.a.van.mazijk@rug.nl

1 Department of the History of Philosophy, Faculty of Philosophy, University of Groningen, $\mathrm{H}$.

W. Mesdagstraat 20, 9718 HH Groningen, The Netherlands 


\section{Introduction}

Originating in a climate dominated by neo-Kantian philosophies, the difficult relation of Husserl's Logical Investigations (henceforth LI) ${ }^{1}$ to Kant's critical philosophy ${ }^{2}$ intrigued scholars even before Husserl's transcendental turn. ${ }^{3}$ Husserl's position to Kant started out antithetically, however, which can be ascribed partially to the influence of Brentano's critical reading on the early Husserl. ${ }^{4}$ It is only in the period just preceding $L I$ that Husserl, now about forty years of age, undertakes a more serious study of Kant, to whom he increasingly 'feels very close' (Husserl 1984, 732).

In spite of such occasional display of kinship in both published writings and personal letters - which usually pertains to the philosophical spirit rather than the content of Kant's writings - near to all mention of Kant in Husserl's entire oeuvre is critical. This is only partially due to Husserl's insistence on demarcating his own phenomenology from the neo-Kantian philosophies. ${ }^{5}$ Husserl seems to have intended the most important book of $L I$ - or certainly the most discussed one ${ }^{6}$ - to uproot the foundations of Kantian epistemology. Indeed, as Husserl suggests in a lecture on Hume and Kant from 1903, the only way to discover any truth in Kant's system is to break it down entirely. ${ }^{7}$ Husserl's subsequent engagements with Kantwhich increased in intensity from thereon-are best understood in this spirit of complete renewal of Kant's thinking, a spirit Husserl also recognized so clearly in Kant, and which he believed was again required to reinstitute philosophy in unprecedented

\footnotetext{
${ }^{1}$ LI was published in two volumes: the first released in 1900, the second in 1901. The fifth and sixth book central to this paper are part of the second volume. My exposition, however, partially relies on the second edition as well, published in 1913. Where the second edition is used in discussing Husserl's explicit mention of Kant, this is indicated in the main text or in a footnote. All translations of Husserl's works are mine, with the exception of Experience and Judgment (1997).

2 References to Kant's Critique of Pure Reason are given with standard abbreviations CPR followed by standard references to the first and second editions: A and B. Quotations derive from the English translation by N. K. Smith (Kant 1929)

3 Husserl's transcendental turn was first publicly announced in the winter lectures from 1906 to 1907 (also a period of intensive Kant studies), but the first published work elaborating on this is Ideas I from 1913. In spite of early interest, there are very few extensive studies of the relation between Husserl and Kant, Kern (1964) forming the most notable exception.

4 As Kern's (1964, 5-22) extensive study demonstrates, Franz Brentano's severely critical reading was in turn influenced by German philosophers Friedrich Lange and Hermann von Helmholtz. Brentano flatly denied the existence of any synthetic a priori cognitions, which he regarded either as entirely unfounded assumptions or as plainly analytic or empirical judgments. According to Kern, Brentano's views left a markedly negative imprint of Kant on the early Husserl. Husserl started lecturing about Kantian philosophy himself in the winter of 1897-1898 and continued to renew his studies of Kant throughout virtually all important phases of his intellectual development.

5 See also Staiti (2014) for an extensive study of Husserl's relation to neo-Kantianism.

6 As the name rightly suggests, the six books of Husserl's $L I$ are first of all logical investigations. The entire first volume is recognized mostly for giving the final blow to psychologism, a movement prevalent in the nineteenth century (and one which Frege had deemed Husserl guilty of in his earlier Philosophy of Arithmetic (1970) from 1891) which reduces ideal laws to psychological ones. It is only in the last two investigations of the second volume that Husserl ventures a deeper philosophical clarification of ideality through a 'descriptive-psychological' or phenomenological analysis of consciousness. Of these two books, the sixth has traditionally received the most attention especially in phenomenological circles.

7 Husserl (1956, 356).
} 
clarity and rigor, from which standpoint alone a final evaluation of Kant's efforts would be possible.

At the relatively early stage of $L I$, however, Husserl's understanding of Kant and of his own philosophy had not yet fully developed. As Fink illustrates, it is only from the later Ideas $I$ that the philosophical direction latently present in $L I$ can become explicit. ${ }^{8}$ That is to say, Husserl's $L I$ does not yet conceive of its problems of intentionality within a transcendental framework. This does not mean, however, that Husserl did not engage with the problems of Kantian transcendental philosophy. To the contrary, textual evidence indicates that the core of Husserl's mature critique of Kant can be traced back to the sixth book of $L I$-namely the criticism that Kant lacked the right concept of a priori upon which to base fundamental epistemological inquiries. Rather than elaborating a systematic critique of this, however, the sixth book of $L I$ can be read as simply positing a better alternative. This means that a substantial critique of Kant's method of inquiry is not to be found in $L I$, and even though the need for it is explicitly alluded to in the first edition, Husserl in fact never produced it. ${ }^{9}$

This paper reconsiders Husserl's theory of knowledge in the sixth book as a criticism of Kant's epistemology. To do so, I first briefly discuss three fundamental aspects of Kant's theory which (I show) Husserl was familiar with and which are essential to his critique of Kant. The first of these is most visibly targeted in the first edition of $L I$, namely (i) the idea of knowledge or objectively justified belief as necessarily involving a cooperation of two faculties. The second and third points are of a methodical nature and closely related. They concern (ii) the concept of a priori guiding Kant's investigation of the necessary structures of knowledge, and (iii) Kant's endeavor to prove that those forms are a priori in us.

Turning to $L I$, the third section of this paper outlines Husserl's theory of intentionality of the fifth book and his intentional account of epistemic justification of the sixth book. In the latter, Husserl makes his principle departure from Kant by specifying justification exclusively in terms of syntheses between so-called meaning and intuitive acts, and thus without reference to a faculty of sensibility. To do so, he needs to re-conceptualize the contribution sensible intuition makes in providing epistemic warrant on Kant's reading to fit his own intentional account. I argue that the act-moment of fullness which belongs to intuitive acts serves to this end. The concept of fullness can therefore be identified as the locus of Husserl's departure from Kant regarding their views on belief justification.

Following Husserl's exposition in $L I$, Kant too narrowly restricted epistemic warrant to sensible intuition because he failed to see the crucial distinction between empty meaning and full intuitive acts. By considering some of Husserl's later elaborations, this criticism of the first (i) point can be traced further to the allegedly biased and 'not radical' (Husserl 1956, 379) methodology of Kant's investigations, which leads to the second (ii) and third (iii) point. Partially drawing on later reflections,

\footnotetext{
8 See Fink (1933, 326).

${ }^{9}$ Husserl did discuss aspects of such a critique in various lecture notes as well as in the brief discussions on Kant in Crisis of the European Sciences.
} 
I show that Husserl considered not only the distinction of faculties but 'all principle obscurities' (Husserl 1984, 733) ${ }^{10}$ of Kant's theory rooted in a deeper problem, namely the failure to discover the right concept of a priori evidence and to develop an intuitive method for investigating structures of experience based on that. I conclude that the sixth book of $L I$ containing a tacit critique of the three core aspects of Kant's theory of knowledge in a way consistent with Husserl's later reflections on Kant. $^{11}$

\section{Three aspects of Kant's theory of knowledge Husserl was familiar with}

This section outlines three basic but fundamental aspects of Kant's theory of knowledge as developed in the first Critique. These are (i) Kant's specification of knowledge or objectively justified belief as necessarily involving sensible intuitions and concepts, (ii) the concept of a priori structures of experience Kant operates with, (iii) his attempted proof that these are a priori in us. In offering this exposition, I simultaneously show that Husserl was familiar with Kant's theory in these three respects. The third section then discusses Husserl's alternative theory in $L I$, after which I extract Husserl's critique of the three aspects of Kant's theory in the fourth section.

As Kant notes at the opening of the Transcendental Logic, all 'our knowledge springs from two fundamental sources of the mind' (CPR A50/B74). Moreover, neither of those sources or faculties can yield knowledge in isolation, and neither can take over the other's role (CPR A51/B76). An experience of knowledge, then, requires that both faculties cooperate. ${ }^{12}$

The first faculty, called sensibility, is defined by 'the capacity for receiving representations through the mode in which we are affected by objects' (CPR A19). The representations thus produced Kant calls intuitions. As representations, intuitions stand out for their 'immediate relation' to the object. Here an object is directly 'given to us' since we are 'affected by that object.'

Whereas sensibility can only produce representations 'in so far as it is in any wise affected', the second faculty, called understanding, has the 'power of producing representations from itself' (A51/B76). The representations the understanding thus produces are called concepts, which combined may form judgments. Whereas sensible intuition is the only form in which an object can be given, it is only through judgment that 'the object is thought' (CPR A50/B74).

\footnotetext{
${ }^{10}$ From the second edition of $L I$ from 1913.

11 Note that whereas I do offer several critical reflections on Husserl's complicated reading of Kant along the way, these usually aim to make clear how Husserl understood Kant exactly. This paper focuses exclusively on Husserl's criticism of Kantian epistemology as it can be extracted from the sixth book of $L I$, and therefore it does not survey the critical neo-Kantian replies to that or, again, Husserl's replies to them. For more on this exchange of thought between Husserl and the neo-Kantians, see Fink (1933).

12 'Neither concepts without an intuition in some way corresponding to them, nor intuition without concepts, can yield knowledge' (CPR A50/B74).
} 
To understand Kant's motivation for the separation of these faculties, it is important to consider that such a divide was not generally accepted before him (CPR A44/ B61). Rationalists such as Descartes, Leibniz, and Wolff did not adhere to anything like it. As a result, they could allow for forms of belief justification which do not necessarily refer back to sensible intuition. By re-conceptualizing knowledge as a cooperation of two faculties, Kant sought precisely to discredit this and make viable a new understanding of justified belief. On Kant's account, sensibility alone can produce the immediate intuitive representations required for judgments to be justified. In other words, for Kant, non-sensible intuitive evidence does not exist (CPR A19/ B34, A51/B76, A68/B92). ${ }^{13}$ Although this narrowing of epistemic warrant to sensible intuition allowed Kant to expel the metaphysical proofs of the rationalists, it is, as I show later, the principle target of Husserl's critique of Kant in $L I$.

For the purpose of understanding Husserl's critique of Kant, it is necessary to delve a bit deeper into Kant's theory of knowledge as a necessary cooperation of two faculties. Within both faculties, Kant specifies further conditions which need to be in place for our judgments to be objectively warranted. According to Kant, there is a necessary form of sensibly intuiting the world as well as one for thinking about it. These forms are universally (for all humans) ${ }^{14}$ necessary; there can be no experiences of knowledge without them. Since they are shared a priori by all of us, these forms simultaneously determine the scope of our objectively and inter-subjectively justified claims about the world. So having first established the divide of faculties, Kant sets himself the subsequent task of exposing these universal forms of experience (through a metaphysical exposition) in order to then reveal how they make cognition possible (in the transcendental deduction).

While tracing the details of these expositions is beyond the scope of this paper, two further points are worth highlighting. The first concerns how Kant understands the concept of a priori with regard to the forms of experience. ${ }^{15}$ In brief, Kant believes his inquiry into the a priori forms of experience requires a complete reduction of all experiential content. To expose them, we must abstract from all possible contents-the intentional correlates —of experience. We can, for instance, as Kant notes, imaginatively isolate our faculty of sensible intuition. Next, we can take out what thinking adds to it as well as all its varying empirical contents. This includes

\footnotetext{
13 'Intuition takes place only in so far as the object is given to us' (A19/B34); 'our nature is so constituted that our intuition can never be other than sensible' (CPR A51/B76); 'without sensibility we cannot have any intuition' (CPR A68/B92).

14 In lectures from 1908, Husserl offers an elaborate critique of this 'anthropological' tension in Kant's Critique, which plays an important role in Husserl's understanding of Kant's failure to develop an a priori investigation of pure consciousness. Kant's philosophy, in spite of being 'transcendental', is said to operate with a picture of human beings as psychophysical objects in nature. The alleged anthropological focus would, Husserl maintains, also show up in Kant's reference to God in his account of the possibility of non-sensible intuition and of the thing in itself (Husserl 1956, 362-363). I do not foreground the criticism regarding Kant's anthropocentrism in this paper, but see especially Husserl (1956, 357-364, 377-381).

$15 \mathrm{H}$. Allison, in this respect, demarcates the use of transcendental a priori in Kant in terms of degree of generality (2010, 23), which seems to match my focus here on abstraction. See also Anderson (2010) for a discussion of Kant's use of a priori in the first Critique.
} 
'feelings' but also 'sight, hearing, touch, [...] sensations of colors, sounds, and heat' (CPR B29, B44, also A29). This way, Kant claims, we discover the a priori forms structuring any act of sensible intuition (namely space and time). A similar exposition is then later executed for the a priori elements of understanding (CPR A70/ B95).

Importantly, on Husserl's reading, this Kantian concept of a priori-as involving a complete reduction of the concrete contents of experience through a kind of formalizing method-is mistaken. In lectures from 1923/1924, Husserl refers to Kant's method of imaginative abstraction as 'peculiar' (Husserl 1956, 212); in Crisis from the 1930s, among other works, he calls Kant's conception of a priori evidence 'mythical' and 'ungraspable' (Husserl 1976, 116-118). Although the precise reasons Husserl has for thinking this become transparent in later writings only, his account of intentionality in $L I$ relies on a different understanding of a priori nonetheless. ${ }^{16}$ For the moment, however, we can take content in noting this, and postpone discussion of Husserl's alternative account until later.

The other important point is that, at least according to Husserl's later thoughts on the matter, Kant had his mind torn on how precisely to account for his suggestion that the a priori forms are absolute conditions of experience. As Husserl elaborates in several lectures from the $1920 \mathrm{~s}^{17}$ as well as in Crisis of the European Sciences from the 1930s, Kant failed to solve this problem, and it ultimately led his theory of knowledge to ruins. This failure, Husserl thinks, amounts to a lack of the right intuitive method of investigating consciousness's essential structures. While $L I$ does not yet elaborate on this matter extensively, it does explicitly identify this problem in the second edition (Husserl 1984, 733). I return to this point of criticism extensively later on.

Indeed, if we look at the first Critique, we can distinguish broadly two strategies Kant has for making the idea of a priori forms of experience plausible. The first and most well-known of these is the infamous 'subjective' exposition of the A-deduction. Here Kant seems to be describing how consciousness synthesizes data from sensible intuition in accordance with pure concepts of the understanding, which involves a proof of their absolute indispensability for experience. Husserl, and many continental thinkers after him, recognized this procedure as essentially phenomenological. That is to say, Kant was allegedly investigating essential structures of synthesis based on the direct intuitive description of immanent consciousness. The problem is, however, that Kant himself had rejected the possibility of a direct inquiry of consciousness based on some special kind of non-sensible intuition. For that reason, following Husserl's interpretation, Kant ultimately could not make sense of his own procedure in the A-Deduction and was forced to abandon it as an

\footnotetext{
16 Moreover, the second edition from 1913 involves a section stating that Kant 'has missed the true phenomenological concept of a priori' (Husserl 1984, 733).

17 Most notably the lectures now published as Kant and the Idea of Transcendental Philosophy from 1924 and Analyses Concerning Passive and Active Synthesis from 1920/21, 1923, and 1925/26, see Hus$\operatorname{serl}(1974,2001)$.
} 
ill-founded piece of psychological inquiry in the second edition (Husserl 1976, 106; 2001, 170-174).

Following Husserl's reading, this would leave only Kant's second strategy intact. This is essentially an inference to the best explanation. To put it bluntly, throughout the first Critique Kant appears to assume that we have certain synthetic a priori cognitions. For some reason, it was plainly evident to him that the propositions of pure mathematics and certain ones in pure natural science, such as 'every event has a cause,' are synthetic a priori, and furthermore that they alone qualify as such (CPR B4-B5). Therefore, the only relevant question is how they are possible, not whether they are possible. It follows that Hume's theory of the derivation of all concepts from experience must be wrong, as it undermines the feeling of necessity of certain concepts we assume is justified. It can subsequently be inferred that these propositions are constructed out of a priori forms 'in us,' since the alternative-deriving them from experience — cannot explain their presupposed absolute validity. As Kant puts it: 'owing to the necessity with which this concept of substance [an a priori concept] forces itself upon us, we have no option save to admit it has its seat in [us] a priori' (CPRB6). Or again: locating these forms in us is the 'only explanation that makes intelligible the possibility of [synthetic a priori cognitions as in] geometry' (CPR B41). ${ }^{18}$

While the A-Deduction did intrigue Husserl, again particularly (but fragmentarily) in later writings, this second strategy plays no significant role in Husserl's earlier or later discussions of Kant. Nevertheless, it is evident that he was aware of it and its apparent weakness. In a later lecture on Kant and Leibniz from 1924, Husserl is critical of the role of the 'regressive transcendental method' which departs from the 'factum' of objective science, which Husserl thinks both Kant and the neoKantians employ (Husserl 1956, 365-376). Likewise, already in 1901 in LI, Husserl notes that Kant is from the outset developing a metaphysical theory of knowledge based on the false aim to 'save' mathematics and natural science (Husserl 1984, 732). It can be concluded, therefore, that at the time of $L I$ Husserl had developed at least some awareness of what he took to be a fundamental problem in Kantian methodology, namely the nature of the evidence onto which transcendental claims are here taken to rest, and that he reflected on his own philosophy in relation to that.

To summarize this brief overview: Kant's account of how we acquire knowledge and justify our beliefs rests on (i) a distinction between sensibility and understanding taken as a fundamental fact of the human cognitive constitution. According to Kant, these faculties must cooperate in order to have a belief objectively justified.

\footnotetext{
18 Apart from the fragments quoted, the inference to the best explanation also figures in the A-deduction, especially A112-113, although arguably less prominently than in other places. Kant further notes that 'since they [absolute realists about space and time] are unable to appeal to a true and objectively valid a priori intuition, they can neither account for the possibility of a priori mathematical knowledge, nor bring the propositions of experience into necessary agreement with it' (CPR A40/B57). Elsewhere, with regard to the Lockean and Humean empirical derivation of concepts through habit, Kant replies that this plainly 'cannot be reconciled with the scientific a priori knowledge which we do actually possess, namely pure mathematics and general science of nature; and this fact therefore suffices to disprove such derivation' (CPR B128 my italics).
} 
Kant subsequently isolates both sources and (ii) claims to obtain the a priori structure of experiences of knowledge by abstracting from all the concrete contents their products may contain. Lastly, (iii) although Kant in the A-Deduction could be seen as flirting with a phenomenological description of a priori structures of consciousness, Kant-at least on Husserl's understanding-lacked the theoretical basis to accept the kind of intuitive method this procedure demanded.

\section{Intentionality, meaning acts, and their fulfillment}

The fifth book of Husserl's $L I$ serves primarily as a preliminary to the sixth book, which is more directly concerned with providing a phenomenological theory of knowledge. As stated at the opening of the fifth book, meaning and objectivity, central to all scientific activity, are essentially brought about in or through intentional acts of consciousness. Husserl further maintains that so-called signitive or meaning acts (these are synonymous) can be verified or justified if they are fulfilled by intuitive acts upon coinciding with them. But in order to understand how that works, a more general account of intentionality is first needed. That is to say, Husserl needs a framework for thinking about how consciousness comports itself to things in general, and this is what the fifth book provides some first steps toward.

Intentional experience, Husserl notes, is an 'important class within the sphere of psychic experiences' (Husserl 1984, 353). This implies that intentionality is not exhaustive of consciousness as a whole. It rather captures that essential part of our lives through which things are given to us. ${ }^{19}$ Every intentional experience involves something that is given, in other words, it involves representation-a concept which does not denote any mediation of experience for Husserl, but rather only the presentation of 'something over-against.' The concept of intentional experience is further terminologically equated with the concept of act. This means that when in LI Husserl speaks of acts of consciousness, he speaks of intentionality, and vice versa (this also goes for his later works).

It is typical of the Husserl of $L I$ to identify phenomenological consciousness with all that is 'really' (reell) ${ }^{20}$ inherent in consciousness. On account of $L I$, all the different types of acts-of consciousness's comportment toward things-belong to the study of consciousness. The object to which an act is related is, however, not considered a part of the act, and likewise does not belong to the study of intentionality (Husserl 1984, 358, 427). The act-structure is said to contain, among others, the appearance of the thing (Husserl 1984, 360-361). The object itself, by contrast, is not a part of it. The conflation of these distinct matters-of the thing-appearance and the appearing thing-is what, according to Husserl, troubled phenomenalists

\footnotetext{
19 See also van Mazijk 2016, where I compare Husserl's later theory of perceptual synthesis to Kant's.

20 Reell (here translated as 'really inherent') functions very differently from the English word 'real'. At no point is the empirically real structure of consciousness at stake in Husserl's phenomenology. Instead, real inherence denotes a certain way in which to speak of contents of consciousness, pointing to those contents that are 'immanent' in consciousness, i.e. those that are lived through, as opposed to the objects at which acts are directed.
} 
such as Berkeley (Husserl 1984, 370-371). The phenomenologist, then, investigates only the act-appearance structure as a distinct subject matter of its own, while disregarding the object in terms of its empirically real structures.

Husserl thinks there are many different ways in which we can be intentionally directed at things. The same object can be the target of different types of acts, as in judging, seeing, remembering, or wishing for the same state of affairs. In LI, Husserl exploits these differences in terms of act-quality. The act-quality can be characterized generally as the way of intending something. So in perceiving or wishing for a cup of coffee on one's desk, different act-qualities establish the same object-relation in different ways.

From section 16 of the fifth book onwards, Husserl introduces another element into the intentional structure, which functions as counterpart to the act-quality: the so-called matter. The matter combined with the quality are said to constitute the intentional essence: that which any intentional act has - although it does not exhaust the complete epistemic essence of an act, which can be postponed until later.

The notion of matter, on Husserl's account, helps accounting for the fact that we can intend the same object in different ways. For instance, in seeing or wishing for the same object, different act-qualities are said to correspond to one matter. Husserl, then, seems to suggest that (i) matter determines object-reference, but also that (ii) the same object-reference implies the same matter. In other words, to say that we can perceive and imagine the same object in different ways amounts to saying that there can be different acts with the same matter. ${ }^{21}$

Yet this does not seem to be Husserl's view exactly. For Husserl also remarks that it is possible for acts to intend the same object while having different matters (Husserl 1984, 497). This implies that the concept of matter is wider than the determination of object-reference-since one object-reference can involve different matters. This, in turn, means the second clause stated above cannot be true after all; the same object-directedness does not yet imply the same matter. The judgments 'Elvis Presley was born in Mississippi' and 'the King of Rock and Roll was born in Mississippi' have the same object-reference, but a different matter-a difference not accounted for by difference in quality (both are assertions). On the one hand, then, Husserl exploits the concept of matter to account for identical object-reference over various act-qualities, but he also uses it in a wider (Fregean) sense to include exactly how object-reference is determined, thereby allowing different matters for one object-relation (Husserl 1984, 429-430, 497).

So far, the fifth book has prepared for Husserl's theory of knowledge in the sixth book by introducing a basic repertoire of distinctions pertaining to intentional consciousness. The most important of these were the act-quality and the act-matterwhich together constituting the intentional essence-and the intentional object, which is not a part of the act. While these concepts should allow us to understand the fundamental ways in which consciousness can relate to objects, Husserl does not

\footnotetext{
21 'There are different ways of intentional directedness at one and the same object, that is to say, there are two acts with the same matter and different qualities' (Husserl 1984, 470). Husserl suggests the same point in the unpublished manuscripts Studien zur Struktur des Bewusstseins, text nr. 4, s. 1.
} 
think they suffice to clarify the phenomenological operations of acquiring and justifying knowledge. This process, central to the sixth book, is captured with the term 'fulfillment' (Erfühlung). The account of fulfillment simultaneously entails the core of Husserl's critique of Kant, namely of the idea (i) that knowledge or justified belief necessarily involves a cooperation of two faculties.

To account for the acquisition and justification of knowledge, the sixth book introduces another crucial distinction within the class of intentional acts. This is referred to as the interpretative form of acts (Husserl 1984, 624), of which Husserl distinguishes two kinds: signitive and intuitive ones. This means that acts can now be classified as either signitive or intuitive (or a mix between both), while all of them in turn have a quality and a matter. The new distinction is of great importance, since, as Husserl notes, all knowledge refers to the relation between signitive and intuitive acts (Husserl 1984, 736). Moreover, it serves, in a way, to replace the Kantian separation of understanding and sensibility.

It is crucial that on Husserl's account signitive acts alone can be defined as meaning (Bedeutung) acts. That is to say, signitive acts are intentional acts which express or give voice to meaning. In the first sections of the sixth book, Husserl puts considerable effort in showing that the meaning of an expressing act is always contained in special signitive acts-which are 'founded' acts—and never, for instance, in a simple 'founding' act of seeing. To sustain this, he offers elaborate discussions of what we today would call demonstrative reference, where the 'place' of the expressed meaning is arguably most difficult to decide. In a demonstrative reference, as in seeing and subsequently expressing 'this is a blackbird,' we have a judgment act tied directly to a perceptual content at which it is directed. In short, Husserl accepts that the perceptual act supplies the meaning act with object-directedness, but he denies that it contains the act of meaning (Husserl 1984, 554). As Husserl puts it, "when I say this, I do not plainly perceive; instead, on the basis of seeing a new act builds itself, which directs itself to it and [...] which is dependent upon it, namely the act of meaning-this' (Husserl 1984, 554 my italics). Although this new meaning act is built onto the perception, it could principally do without it (Husserl 1984, 556), which should prove that the expressed meaning is not 'in' the perceptual act.

Husserl thus separates the pure act of meaning or expressing something from (in this example) the concrete act of seeing. The latter here provides all the richness of content; the former only the act of expression. For this reason, Husserl can refer to the act of meaning as principally a completely empty act (Husserl 1984, 607). To be sure, meaning acts are in reality rarely completely empty. If, for instance, someone would shout, 'Look out the window!' and you would do so without seeing anything remarkable, you would have an empty meaning intention which awaits the fulfillment only the perception of something peculiar could give. Yet this empty intention already operates with a tacit scope of possible adequately fulfilling acts-for instance, things with a sufficient degree of peculiarity-which means the meaning act was not completely empty after all. ${ }^{22}$

\footnotetext{
${ }^{22}$ In later works, Husserl analyzes this implicit pattern of expectations, which is in place in any intentional directedness, in terms of consciousness's horizonal structure.
} 
The emptiness of meaning acts becomes clearer by contrasting it to the complete class of intuitive acts. The class of intuitive acts, on Husserl's view, includes all acts that are capable of giving fullness to empty meaning acts. Fullness here is best understood very generally as giving something. The prime example of an intuitive act is a simple perception. While a simple perception can certainly share objectreference with a meaning expressing act, the former nevertheless seems to involve a certain surplus which the expression lacks. This peculiar surplus is, Husserl notes, the fullness or representative content intuitive acts have. The fullness is thus not an act itself, but an act-moment next to the quality and matter. It is because of the fullness of intuitive acts that we say that through them we grasp the intended thing; we behold it, rather than having a mere empty expression of it.

Simple perception is the canonical example of an intuitive act. Because of that, it may now seem tempting to understand the moment of fullness of intuition as the plain result of the sensory content involved in perception. Intuition could then be understood as letting us behold the object simply because sensations put us in real contact with it. This seems to be the case on Kant's account, where sensibility produces an intuitive representation of an object on ground of being affected. ${ }^{23}$

But fullness, on Husserl's account, is not due to a sensory contact of a faculty of intuition to empirical reality. In fact, on Husserl's account, fullness or representative content is not exclusively a moment of acts of sensible intuition. We also have it, among others, in memory. An act of remembering, on Husserl's view, likewise involves an intention which goes out and grasps something in degrees of fullness. For instance, if I try to remember the town I grew up in, I grasp it imaginatively; I 'see' buildings from this or that side; I imaginatively wander the streets, and so on. I can ask myself what color this or that building used to be, and subsequently grasp that color with intuitive evidence. To be sure, the evidence I thus attain is not the same as of perceptual intentionality; only the latter has the character of giving the real thing; it peculiarly claims to stand in need of no further fulfillment (Husserl 1984, 589). ${ }^{24}$ Yet certain non-sensible acts, Husserl insists, are capable of providing fullness to a corresponding meaning act (Husserl 1984, 646-647). Given that the capacity to provide fullness to meaning acts defines intuitive acts in general, Husserl thinks memory can be called a type of intuition.

However, according to Husserl, closer scrutiny reveals that memory and perception together cannot provide fullness to all types of meaning acts we are familiar with. One can, for instance, have an empty meaning intention of a state of affairs or a mathematical formula without thereby grasping it, beholding the sense of the proposition itself in immediate proximity. One can express, say, the Pythagorean Theorem without having an intuition in the sense of an act which gives the sense

\footnotetext{
${ }^{23}$ In lectures from 1903, Husserl praises Hume for taking immediate, living experience as a starting point for his theory of knowledge, as opposed to Kant and Locke, who start problematically with the affection of the subject by a presumably mind-external object, and thus depart from a duality of subject and object (Husserl 1956, 352-353).

24 An exception should be made for perceptions of images, maps, statues, and the like (Husserl 1984, 605-606). Such intentions involve perceptual fullness, but they lack the claim of giving the real thing as in an ordinary perception.
} 
expressed, that is, grasps its meaning (Husserl 1984, 690-691). Clearly, this intuition of the Pythagorean Theorem cannot be of a sensible kind. Ideal objects cannot be seen with the senses; only their symbolically representing signs can. Yet acts expressive of ideal objects can achieve fullness. We have, therefore, according to Husserl, acts which can legitimately be called intellectual intuitions: acts which give us ideal objectivities that provide fullness to empty meaning acts. ${ }^{25}$

Something similar is said to hold for the intuition of states of affairs. According to Husserl, simple perception does not give us states of affairs; it only gives us objects-a view he consistently maintained and elaborated in later works. If we think of the state of affairs 'A is B,' or 'either A or B,' what shows in simple perception is ' $A$ ' and ' $B$ ' in each case. However, their relation - the 'is' and 'or' — cannot be intuited in simply perception. For Husserl, then, simple perception is incapable of providing fullness to categorial meaning intentions, since the relevant categorial relations cannot be simply seen.

To be sure, it would be phenomenologically inapt to suggest that simple perception gives us only completely isolated objects. Things always appear as standing in certain relations to other things. But what matters is that, Husserl claims, simple perception differs from categorial intuition in offering an immediate, effortless grasp of the thing, as in a 'single blow' (Husserl 1984, 674). ${ }^{26}$ We cannot, by contrast, effortlessly grasp the state of affairs 'that the mug is on the table,' or 'that the mug and the pen are black.' Explicating categorial relations such as 'being' and 'conjunction' demands a new, higher-order, indeed intellectual act. Since categorial forms are not sensibly given, Husserl conceives of them and of universals alike as 'objects' of a new sort, a kind of strictly 'super-sensuous' objects (Husserl 1984, 673).

Perceptual, categorial, and universal intuition are perhaps the most important classes of intuition. Husserl believes, however, that they can be unified into a single theory of knowledge because they share a single common feature: the distinction between empty and full acts applies to all of them. All these acts, Husserl notes, have a unique epistemic essence (Husserl 1984, 626) comprising of the matter, quality (together the intentional essence), and the moment of fullness of the intuitive act. For any judgment-by itself an empty meaning act - to find its intuitive warrant, it is necessary that it is brought together into a single conscious experience with an appropriate act providing fullness. Hence the justification of a judgment is, Husserl maintains, experienced as a kind of coincidence between these two acts. In such a

\footnotetext{
${ }^{25}$ Needless to say, this view was not well received by the neo-Kantians, who believed Husserl's theory of ideal objects falsely led to intuitionism and to an ontologizing of what are really operations of thought. I will not go into the criticisms of the neo-Kantians here, but see for instance Zocher (1932) for an illustration of it, and Fink (1933) for a reply to this that was approved by Husserl.

${ }^{26}$ This does not withstand that perception is further composed of other elements. It involves, for instance, a continuous synthesis of constantly changing perspectival intentions into a single conscious experience of an object. But this, according to Husserl, does not alter the fact that perception is a simple act.
} 
coincidence, the fullness of the intuitive act 'fulfills' the empty meaning act-hence the term synthesis of fulfillment. ${ }^{27}$

Because there are so many types of act-appearance relations, there are also many different kinds of fulfillment-both in theoretical and practical domains. The concept of fulfillment applies, for instance, in having the expectation to hear a certain song played on the radio. Here, one executes an empty anticipatory act which can be fulfilled only by hearing that particular song being played. Likewise, in looking around the house for one's car keys, one may consciously entertain an empty thought of the keys which awaits the satisfaction only a synthesis with a perceptual act of those keys could give. In a more theoretical setting, we can imagine one struggling to understand a particular technical notion in the work of a philosopher. Here, one experiences an (to an indefinite degree) empty meaning intention of the relevant concept, which awaits fulfillment through the intellectual intuition of its meaning.

Generally speaking, if the right intuition is successfully brought into coincidence with the meaning intention, the latter finds its evidence in the former. ${ }^{28}$ Husserl acknowledges that there are various levels of such evidence, of better and worse intuitive warrant (Husserl 1984, 650-651), and a variety of both contingent and necessary factors may determine this. ${ }^{29}$ In the ideal case of so-called adequate givenness, however, 'the object meant is in the strict sense given in our intuition, and given as just what we think and call it' (Husserl 1984, 648). ${ }^{30}$ Adequate givenness, then, as a perfect synthesis of coincidence, is the equivalent of perfect correspondence of thought and object (Husserl 1984, 648).

To summarize: by focusing on the essential class of intentional acts of consciousness, Husserl first distinguishes quality from matter. In the subsequent investigation, Husserl claims that some acts are empty signifying acts, whereas others are characterized by providing intuitive fullness. This depends on the act's additional quality of having fullness. This way, Husserl can subsequently specify epistemic justification as the fullness provided by any type of intuitive act to a meaning act, a process aptly referred to as a synthesis of fulfillment.

\footnotetext{
27 According to Husserl, it is not necessary for fulfillment to take place that the synthesis between the meaning and intuitive act is itself consciously experienced. Instead, it is usually the object to which the attention goes out; it is identified and recognized as being there (intuited with fullness) just as it is (emptily) meant. Regarding the question of what coincides exactly, Husserl notes it is not both acts entirely but rather the act-matter (object-reference) which comes up for the synthesis of coincidence (Husserl 1984, 596).

${ }^{28}$ Moreover, fulfillment is said to find its basis specifically in the fullness of the intuitive act, as an actmoment next to quality and matter. As Husserl writes, it is 'only its [the intuitive act's] representative content [its fullness] which really assists the signitive act' (Husserl 1984, 619). So although Husserl notes that the coincidence pertains to the matter of the signifying act, the intuitive warrant a successful coincidence may bring is specifically due to the fullness of the intuitive act. Precise interpretations of this theory vary in the literature. See for instance Bernet's (1985) reading, and particularly Hopp's (2008, 225-226) for an overview of some of the possible ways to interpret the concept of fulfillment.

29 As Husserl elaborates particularly in later manuscripts, the norm for what qualifies as evidence for any particular act - practical or epistemic — is ultimately set by the practical aims of the intender.

${ }^{30}$ See also Husserl (2004b, 144-148) for a similar exposition dating already from 1898 .
} 


\section{The sixth book as a critique of Kant's theory of knowledge}

In this section I focus on the covert critique of Kant which Husserl's theory of knowledge in the sixth book of LI contains. Regarding Kant, I earlier outlined three core ideas that are central to Husserl's interpretation: (i) that the justification of beliefs necessarily involves a cooperation of a faculty of sensibility and understanding; (ii) that the discovery of the a priori structures of knowledge requires abstracting from all experiential contents; and (iii) that there is no intuitive method available for the procedure of discovering these a priori structures.

Of these three points, the first (i) is the most clearly targeted in LI. On Husserl's picture, epistemic justification is entirely a matter of synthesis, namely of a synthetic coincidence between empty and full acts. Sensible experience is not the only possible type of intuitive warrant; in fact, as we saw earlier, certain types of meaning acts cannot find their warrant in sensible intuition at all. Kant, by contrast, has no other positive conception of intuition than the one provided by sensibility. ${ }^{31}$ Kant deemed this restricted necessary to end the rationalist quest for knowledge beyond possible sense experience. But in doing so, Husserl claims, Kant overlooked the essential phenomenological kinship of sensible, categorial, and universal intuition, to the extent that the latter two are not recognized at all. Kant therefore failed, as Husserl remarks explicitly in 1901 in $L I$, to 'reach out to the fundamental widening of the concepts of intuition and appearance to the categorial [and eidetic] realm' (Husserl 1984, 732).

Kant, then, could not discover the genuine operations of justifying beliefs, which Husserl takes to be due to Kant's postulation of a metaphysical distinction of faculties which supposedly must cooperate to produce knowledge. ${ }^{32}$ However, the source of these problems, Husserl thinks, points to a still deeper obscurity. Kant's theoretical mistakes rest on even more fundamental obscurities in method. In spite of offering no elaborate discussions on this matter, the first edition of $L I$ already hints at the necessity of a more systematic investigation into Kant's methodological failures: 'How big the temptation is exactly to let these oppositions flow into each other would be shown by a critique of Kant's theory of knowledge' (Husserl 1984, 731-732). Husserl, then, was aware not only of the thematic relation of his work to Kant's, but further had at least some understanding of the deeper problems of Kantian methodology and of how his philosophy could help reveal those.

\footnotetext{
31 Mathematical a priori cognition, for Kant, refers to the pure form of sensible intuition, and thus forms no exception to this conception. Still, the emphasis on 'positive' here is important, since Kant does allow the formal coherence of the idea of non-sensible intuition, which is crucial to his account of the concept of noumenon. See especially Adams (1997) for a discussion of this.

32 The problem of Kant's faculty distinction is not, according to Husserl, restricted to his theoretical philosophy, but likewise affects his practical philosophy. In his lectures on ethics, Husserl notes that 'the whole contrast between sensibility and reason, in which on the side of sensibility stands the sensuousness of sensation as well as that of feelings and instincts, and on the side of reason the non-sensuous categories which first shape sensibility, is fundamentally wrong' (Husserl 2004a, 220). See also Dodd (2009) for Husserl's work on ethics in relation to Kant's practical philosophy, and Melle (1991) for a general assessment of the development of Husserl's ethics.
} 
Many of the additions in the second edition of LI in 1913 illustrate Husserl's increased awareness of the source of Kant's fallacies understood the source of Kant's fallacies. He there writes the following:

All principle obscurities (Unklarheiten) of the Kantian critique of knowledge have to do with the fact that Kant has not made clear the unique nature (das Eigentümliche) of pure 'ideation,' of the right survey of conceptual essences and of the essential laws of universal validities, and that he thus failed to see the phenomenologically true concept of a priori (Husserl 1984, 733).

In this fragment Husserl points to Kant's alleged failure to discover the right method for investigating 'essential laws', a failure in turn said to relate to Kant's false conception of a priori. Moreover, this together is said to be the source of 'all principle obscurities' in Kant's philosophy. While this latter phrase must be taken quite seriously, it is helpful to first zoom in specifically on (ii) the nature of the evidence involved in Kant's exposition of the a priori structures of knowledge. For this, as discussed earlier, Kant uses a method of abstraction which supposedly yields the formal a priori elements of knowledge. Husserl discusses this approach in a relatively early lecture from 1908 (Against Kant's anthropological theory):

Kant confuses the knowledge which subjectivity produces out of itself by considering its own functioning — which [for Kant] is a priori just insofar as it has nothing to do with the nature of the materials which 'come from without' - with a priori knowledge in the genuine sense. [For Kant,] to refer back to the materials of sensations is to know a posteriori. (Husserl 1956, 364)

Husserl suggests here, somewhat cryptically, that in trying to discover the a priori structure of knowledge, Kant hypothesizes a distinction within experience between the necessary and contingent, and refers the latter to sensible materials. Conversely, therefore, in order to attain the a priori elements of experience, experience must be imaginatively stripped of all its concreteness, hence formalized. According to Husserl, however, this procedure is flawed because the formal conception of a priori guiding it is wrong. Again following Husserl's 1908 lecture, Kant basically inherits the theory of forms from Leibniz (the latter's nihi intellectus ipse), ${ }^{33}$ but does not think through the concept of a priori undergirding it.

To understand this dimension of Husserl's complicated criticism it is necessary to consider his critique of the formal-mathematical understanding of a priori, which is best done on the basis of a collection of manuscripts edited by Landgrebe in the mid-1930s. ${ }^{34}$ The problem, Husserl explains there, does not so much concern the concept of a priori, but rather what it means to hold something in absolute certainty, that is: the nature of a priori evidence. The right account of this, Husserl maintains, does not demand a process of abstraction or emptying out of experiential content. Instead, it is (iii) the intuition of a universal truth (Wesenschau); it is to intuit

\footnotetext{
33 'The hypothesis of Leibniz's intellectus ipse does not clarify anything. The hypothesis says that there are concepts which the mind produces purely out of itself and which do not stem from irritations from outside; also that the supposedly a priori laws which are built from these concepts express lawful regularities which belong purely to the immanent being of the mind. Kant takes this over and makes the theory of forms out of it' (Husserl 1956, 379).

34 This collection of manuscripts is now known as Experience and Judgment (Husserl 1997).
} 
directly and with absolute certainty that something could not possibly be otherwise without ceasing to be what it by its essence is. This intuition of essential structures has everything to do with pure possibility. An a priori proposition is one which holds valid in all possible worlds. Because it is valid in all possible imagined cases, it is inconceivably otherwise, hence $a$ priori.

Husserl thinks Euclidean geometrical propositions are examples of regionally valid a priori propositions (valid within a Euclidean manifold). However, according to Husserl, 'there is not the slightest reason to consider the methodological structure of a priori thinking [...] as an exclusive property of the [formal] mathematical sphere' (Husserl 1997, 353). If we consider the act of intuiting essences phenomenologically, we see that the capacity for free variation of possible worlds is 'everywhere the same' (Husserl 1997, 354). Hence 'from every concrete actuality, and every individual trait actually experienced in it or capable of being experienced, a path stands open to the realm of ideal or pure possibility and consequently to that of a priori thinking' (Husserl 1997, 353-354).

A priori knowledge, then, 'means apodictic insight [intuition] in essential structures (Wesenszusammenhang)', a capacity by no means restricted to formal science (Husserl 1956, 364). The deepest mistake Kant made, according to Husserl, is to never have seen this. Kant thought the a priori investigation of the structures of our experiences of knowledge required abstracting from all sensible materials. In excluding 'feelings,' 'sight, hearing, touch, [...] sensations of colors, sounds, and heat' (CPR B29, B44), Kant endorsed a formally derived concept of a priori. As a result, Kant failed to appreciate that those experiences in fact also stand under their own essential laws which can be investigated a priori in phenomenological purity. He wrongly restricted the inquiry into structures of experience to a limited set of abstract forms, and discarded all possible judgments pertaining to concrete experiential content as a posteriori.

According to Husserl, however, for the allegedly pure forms thus yielded as well as for the distinction between a priori and a posteriori which undergirds it, there simply is no genuine intuitive evidence available. In 1908, Husserl remarks that for Kant's most important distinctions-between two faculties of experience, between the appearance and thing in itself, ${ }^{35}$ and of twelve categories of understanding, among others - there is no intuitive evidence available. It is all 'groundless metaphysics' (Husserl 1956, 362). Even if any of it somehow happened to be correct,

\footnotetext{
35 'In talking about things in themselves he [Kant] presupposes that they are something [etwas], that, as objects [Gegenständen], something belongs to them, even though we cannot know anything about that. God knows better' (Husserl 1956, 363). This fragment shows Husserl believes Kant's concept of a thing in itself undermines a correct phenomenological thinking in essences. For Husserl, the essence of an object in general is governed by certain essential laws that can be discovered phenomenologically. Kant, however, Husserl thinks, stretches the concept of object to a noumenal world through reference to the possibility of divine non-sensible intuition-a line of thought which, Husserl maintains, contradicts the 'essence of object in general' as discoverable in eidetic intuition As an interpretation of Kant, this reading might be challenged, but this is beyond the scope of this paper. I have argued elsewhere that Husserl and Kant can be construed as being much closer on the logical possibility of a world beyond ours than Husserl here acknowledges, but this mostly depends on how one interprets Kant on this highly controversial subject.
} 
it 'would not mean that we know that' (Husserl 1956, 379-380 my italics). ${ }^{36}$ This explains the seriousness of Husserl's claim in $L I$ mentioned earlier-that all principle obscurities of Kant's philosophy can be brought back to the lack of a correct understanding of a priori intuitive evidence.

Much later in Crisis of the European Sciences, which contains Husserl best known discussions of Kant, Husserl forcefully states that Kant's core concepts are 'uniquely unclear,' because they principally 'cannot be brought back to a direct evidence delivering sense formation' (Husserl 1976, 118). But this, we now see, merely repeats the same contention that struck Husserl from very early on already, namely that none of Kant's investigations or any of the presuppositions on which they rest can be brought back to a priori evidence. Kant's failure to specify justification in terms of intuitive fullness and instead as a cooperation of faculties thus turns out only a surface problem. The root of the problem, which infects Kant's entire system, is that its results nor method derive from the sort of insight onto which alone a fundamental epistemology can be based, namely apodictic intuition.

It is useful to draw out clearly that from Husserl's perspective, the importance of this difference in theory of evidence can hardly be overstated. Not only does Husserl identify the problem of evidence as the source of all of Kant's philosophical mistakes. Moreover, it marks the difference between Kantian philosophy and his own phenomenology. In whatever ways Kant's account may resemble Husserl's-for instance the emphasis on synthesis in the A-Deduction or the a priori role of space in object-constitution-Husserl considers them mere surface similarities. A claim may be true, but it also needs to be justified. What matters most to Husserl is that, even if Kant was right about certain matters, he allegedly did not know this-since knowing here means essential insight, the concept of which Kant lacked.

Drawing on some of the later works thus seems necessary to put all the pieces of Husserl's critique of Kant in $L I$ in the right place. Nevertheless, the sixth book of $L I$-even in the form of its first edition-is already founded exactly upon this understanding. All the distinctions pertaining to acts - the matter, quality, meaning and fullness-are a priori distinctions in essence based on the immediately intuitive and a priori survey of consciousness. In the second edition of $L I$, Husserl therefore only needed to add that Kant 'could not grasp the only possible goal of a strict scientific theory of knowledge, namely the goal of investigating the pure essential laws that govern the acts as intentional experiences in all its forms of objective meaning-giving' (Husserl 1984, 733). But the same point these new additions make is reflected already in a lecture from 1903, only two years after LI: 'Kant overlooked that transcendental philosophy can hope for nothing other than to clarify the sense of knowledge and its validity, and that clarifying here means nothing but going back to the origin, to the evidence, therefore to consciousness, in which all concepts of knowledge are intuitively realized' (Husserl 1956, 356).

\footnotetext{
36 Something like this seems to be the case for Kant's theory that space is a priori involved in outer sensible experience, which, as Husserl writes in lectures from 1923/1924, in fact involves a certain truth which can be intuitively verified, even though Kant did not have the right theory of evidence to sustain the claim (Husserl 1956, 213).
} 
To conclude this section: Husserl thought Kant (i) misconstrued justification in terms of a cooperation of two faculties, a misunderstanding ultimately due to (ii) false ideas about a priori evidence and (iii) a too narrow conception of intuition. Because of these mistakes, Kant could not realize an investigation of consciousness for the sake of a fundamental theory of knowledge based exclusively on intuitive, a priori insight into structures of consciousness. As a result, Husserl believed Kant's philosophy stranded in a 'groundless metaphysics,' and the whole field of pure consciousness, the possibility of its intuitive and a priori survey, and the vast scope of the problems of intentionality belonging to it could never dawn upon him.

\section{Conclusion}

This paper discussed Husserl's theory of fulfillment in the sixth book of $L I$ as a criticism of Kant's theory of knowledge. For the most part, the sixth book re-conceptualizes the Kantian account of belief justification as a cooperation of sensibility and understanding in terms of a synthesis of fulfillment between intuitive and meaning acts. The contribution sensibility makes in providing epistemic warrant on Kant's account is here replaced by the moment of fullness belonging to intuition, which includes not only perceptual but also categorial and eidetic acts.

At the surface, it seems Kant's alleged failure to specify justification in terms of fulfillment is the core of Husserl's critique of the Kantian theory of knowledge. Husserl, however, takes this error to indicate an even more fundamental one: the failure to recognize the right conception of a priori intuitive evidence on which all fundamental epistemological inquiries are to be based.

To close, it should be emphasized that it might be ill-founded to try to understand Husserl's critique of Kant in isolation from his own philosophical enterprise. Husserl had the peculiar custom to understand philosophy as a single, progressive, and universal task in which all individual thinkers partake. Kant, in this respect, is read by Husserl as he read all others: as a precursor of philosophy's genuine historical end-form. This end-form, as Husserl increasingly stressed, is his own philosophy. Accordingly, it is probably best to understand the critique of Kant drawn out in this paper in the light of Husserl's attempted self-understanding, rather than as a Kant interpretation in its own right. This, indeed, may go a long way explaining why the need for a more rigorous critique of Kant's epistemology, a need appealed to already in the first edition of $L I$, was one ambition Husserl's long career left unfulfilled.

Open Access This article is distributed under the terms of the Creative Commons Attribution 4.0 International License (http://creativecommons.org/licenses/by/4.0/), which permits unrestricted use, distribution, and reproduction in any medium, provided you give appropriate credit to the original author(s) and the source, provide a link to the Creative Commons license, and indicate if changes were made.

\section{References}

Adams, R.M. 1997. Things in themselves. Philosophy and Phenomenological Research 57(4): 801-825. 
Allison, Henry E. 2010. The critique of pure reason as transcendental phenomenology. In The Cambridge Companion to Kant's Critique of Pure Reason, ed. P. Guyer. Cambridge: Cambridge University Press.

Anderson, R.Lanier. 2010. The introduction to the Critique: Framing the question. In The Cambridge Companion to Kant's Critique of Pure Reason, ed. P. Guyer. Cambridge: Cambridge University Press.

Bernet, Rudolf. 1985. Perception, categorial intuition, and truth in Husserl's sixth logical investigation. In The Collegium Phaenomenologicum, the First Ten Years, ed. J.C. Sallis, G. Moneta, and J. Taminiaux. Den Haag: Kluwer.

Dodd, James. 2009. Husserl and Kant on Persönlichkeit. Santalka. Filosofia 17: 29-38.

Fink, E. 1933. Die Phänomenologische Philosophie Edmund Husserls in der Gegenwärtigen Kritik. Kant Studien 38(1-2): 319-383.

Hopp, Walter. 2008. Husserl on sensation, perception, and interpretation. Canadian Journal of Philosophy 38: 219-246.

Husserl, Edmund. 1956. Erste Philosophie (1923/4). Erste Teil: Kritische Ideengeschichte. Husserliana VII, ed. R. Boehm, Den Haag: Martinus Nijhoff.

Husserl, Edmund. 1970. Philosophie der Arithmetik. Mit ergänzenden Texten (1890-1901), ed. L. Eley, Den Haag: Martinus Nijhoff.

Husserl, Edmund. 1974. Kant and the idea of transcendental philosophy. Southwestern Journal of Philosophy 5: 9-56.

Husserl, Edmund. 1976. Krisis der europäischen Wissenschaften und die Transzendentale Phänomenologie: Eine Einleitung in die Phänomenologische Philosophie. Husserliana VI, ed. W. Biemel, Den Haag: Martinus Nijhoff.

Husserl, Edmund. 1984. Logische Untersuchungen. Band I-II, Husserliana XIX/1-XIX/2, ed. U. Panzer, Den Haag: Martinus Nijhoff.

Husserl, Edmund. 1997. Experience and judgment: Investigations in a genealogy of logic. Evanston: Northwestern University Press.

Husserl, Edmund. 2001. Analyses concerning passive and active synthesis: Lectures on transcendental logic. Husserliana Vol. IX, ed. R. Bernet, Translated by A. Steinbock. Dordrecht: Kluwer.

Husserl, Edmund. 2004a. Einleitung in die Ethik. Vorlesungen Sommersemester 1920 und 1924. Husserliana XXXVII, ed. H. Peucker. Dordrecht: Kluwer.

Husserl, Edmund. 2004b. Wahrnehmung und Aufmerksamkeit: Texte aus dem Nachlass (1893-1912). Husserliana XXXVIII, ed. T. Vongher, R. Giuliani. Dordrecht: Springer.

Kant, Immanuel. 1929. Immanuel Kant's critique of pure reason. Translated by N. K. Smith. London: MacMillan and Co., Limited.

Kern, Iso. 1964. Husserl und Kant: eine Untersuchung über Husserls Verhältnis zu Kant und zum Neukantianismus. Den Haag: Martinus Nijhoff.

Melle, Ullrich. 1991. The development of Husserl's ethics. Études Phénoménologiques 7: 115-135.

Staiti, Andrea. 2014. Husserl's transcendental phenomenology: Nature, spirit, and life. Cambridge: Cambridge University Press.

van Mazijk, Corijn 2016. Kant and Husserl on the contents of perception. South Journal of Philosophy 54(21): 276-287.

Zocher, R. 1932. Husserls Phänomenologie und Schuppes Logik. München: Reinhardt. 